\title{
Spying on Americans: US Intelligence, Race Protests, and Dissident Movements
}

\author{
An Applied History Analysis
}

\author{
Calder Walton \\ Kennedy School of Government, Harvard University, Cambridge, MA, USA \\ calder_walton@hks.harvard.edu
}

Received June 2021 | Accepted October 2021 |

Published online December 2, 2021

\begin{abstract}
Protests against racism erupt in cities across America. A White House, under siege, believes a vast conspiracy is at work, and, to uncover it, instigates a policy to spy on Americans. This is not the United States in 2020 , but half a century earlier. Using a wealth of declassified records, this article explores a domestic intelligence collection program (CHAOS) instigated by two successive US administrations and conducted by the Central Intelligence Agency in the late 196os and early 1970s. By studying this historical chapter, we observe how quickly an agency, equipped with intrusive powers, can infringe on Americans' civil liberties when tasked by a US president. Applying this case to our contemporary context, this article argues that robust whistleblower procedures, as well as informal oversight, are powerful defenses against such abuses. Understanding why C HAO occurred is an essential public policy first step to prevent similar abuses happening again.
\end{abstract}

\section{Keywords}

intelligence - National Security - Civil-Liberties - Black Lives Matter

Following George Floyd's death in Minneapolis, Minnesota, in May 2020, protests against police violence erupted in cities across the United States and soon spread overseas. As some protests turned violent, President Donald J. 
Trump declared them the work of a conspiracy, orchestrated by the hidden hand of "professional anarchists" and a terrorist organization, "ANTIFA". Both of Trump's claims were misleading: ANTIFA is not an organization, but instead a loosely affiliated association of mainly left-wing activists, some of whom are violent. ${ }^{2}$ During Black Lives Matter periods of civil unrest, US police reportedly undertook extraordinary measures to collect intelligence ("spy") on Americans. US surveillance aircraft were reported flying over crowds in major US cities and footage of plainclothes police officers emerged, arresting people and bungling them into unmarked cars. ${ }^{3}$ This raises serious legal issues under the First Amendment of the US Constitution, which provides people the right of peaceful assembly, and its Fourth Amendment, preventing unreasonable searches - or surveillance. Meanwhile, Trump's specter of ANTIFA distracted from violence by white nationalism, which exploded with the January 6, 2021 attacks on the US capitol in Washington, D.C. ${ }^{4}$

It is frequently said that those who do not learn from history are doomed to repeat its mistakes. While history never repeats itself, it does rhyme, as Mark Twain reputedly said. The year 2020 is not the first time when the White House has viewed domestic race protests, and other dissident movements, as part of a coordinated conspiracy, rather than problems swelling from within US society itself. Using an Applied History methodology, this article reveals the long history of US administrations seeing conspiracies where there were none and using clandestine US intelligence agencies to collect intelligence ("spy") on protest movements in the United States. This happened in the late 196os and early 1970s. ${ }^{5}$ In doing so, this article provides warnings and lessons to US society about a powerful, overreaching, executive branch that views political dissident

1 Donald J. Trump, "The United States of America Will Be Designating Antifa as a Terrorist Organization.," Twitter, May 31, 2020, https://twitter.com/realDonaldTrump/status/126712964 4228247552. It is unclear to this author why being an "anti-fascist" should be something bad, as described by "conservative" contemporary pundits. The history of the twentieth century suggests otherwise.

2 Meg Kelly and Elyse Samuels, "Who Caused the Violence at Protests? It Wasn't Antifa.," Washington Post, June 20, $202 \mathrm{O}$.

3 Joan E. Greve, "Federal Officers Are Using Unmarked Cars to Arrest Portland Protesters," The Guardian, July 17, 2020.

4 Office of the Director of National Intelligence, "Domestic Violent Extremism Poses Heightened Threat in 2021," March 1, 2021, https://www.justice.gov/opa/press-release/file/1376981/ download; Kathleen Belew, Bring the War Home: The White Power Movement and Paramilitary America (Cambridge, MA: Harvard University Press, 2018).

5 See Athan G. Theoharis, Spying on Americans: Political Surveillance from Hoover to the Huston Plan (Temple University Press, 1978); Loch K. Johnson, A Season of Inquiry: The Senate Intelligence Investigation (Lawrence: The University Press of Kentucky, 2015). 
movements as targets for investigation. Although technologies for intelligence collection about protest movements have changed today from the past, the intelligence and national security principles involved, and dangers to US society, have not.

This article makes three principal arguments: first, the basis for US intelligence agencies investigating domestic race protest movements was historically rooted in a legitimate concern - that the Soviet Union was using them for subversion within the United States. However, this valid concern was proved to be inaccurate, as the CIA correctly reported to the White House at the time. The Agency's contemporary assessments were later confirmed by its espionage against the Soviet Union, from Soviet defectors, and Soviet intelligence archives smuggled to the West. Second, instead of using intelligence to inform their decisions about domestic protest groups, two successive White House administrations, those of Lyndon B. Johnson and Richard Nixon, used US clandestine agencies to find evidence to support their preconceived ideas. On White House instructions, US intelligence conducted a large-scale, and illegal, domestic spying program, codenamed "MHCHAOs" (usually shortened to "CHAOs") by the Central Intelligence Agency (CIA), and "COINTELPRo" by the Federal Bureau of investigation (FBI). Third, the history of these operations provides a warning for contemporary American society: there are risks of "mission creep" when an intelligence community, equipped with intrusive powers, is tasked by political leaders to uncover a (non-existent) conspiracy attacking society.

Our methodology here is Applied History: the express effort to use the past to inform contemporary policy and decision-making. There is a long tradition of history being used to inform public policy, by studying and applying analogies from the past, while equally avoiding their misapplication to contemporary contexts - the abuse of history, as anachronistic "presentism". ${ }^{6}$ Currently

6 Marc Bloch, The Historian's Craft (New York: Knopf, 1953), 11; R.G. Collingwood, The Idea of History (Oxford: Clarendon Press, 1946), 406; John Lewis Gaddis, The Landscape of History: How Historians Map the Past (New York: Oxford University Press, 2002), 3; Gordon S. Wood, The Purpose of the Past: Reflections on the Uses of History (New York: Penguin, 2008), 3, 13-14; Stephen Vaughn, ed., The Vital Past: Writings on the Uses of History (Athens, GA: University of Georgia Press, 1985), 10, 376; Richard J. Evans, In Defense of History (New York, NY:W.W. Norton \& Company, 2000), 4, 173; Margaret MacMillan, Dangerous Games: The Uses and Abuses of History (Toronto: Viking Canada, 2008), 154; Paul Ricoeur, Memory, History, Forgetting (Chicago, IL: University of Chicago Press, 2006), 238; Hal Brands and Jeremi Suri, eds., The Power of the Past: History and Statecraft (Washington, DC: Brookings Institution Press, 2015), 2, 15-16; Philip Zelikow, "The Nature of History's Lessons," in The Power of the Past: History and Statecraft, ed. Hal Brands and Jeremi Suri (Washington, DC: Brookings Institution Press, 2015), 281-310; Eliot A Cohen, "The Historical Mind and Military Strategy," Orbis 49, no. 4 (2005): 
experiencing a boom of scholarly and public policy interest, Applied History should not be considered as having a single didactic methodology. Instead, as one scholar has eloquently put it, the purpose of studying and applying history is to provide "historical sensibility" when thinking about contemporary policy choices. With that in mind, this article's methodology finds inspiration from the work of two seminal scholars, Ernest May and Richard Neustadt, in their book Thinking in Time: assessing similarities and differences between the past and present. ${ }^{7}$ This is the essence of Applied History's methodology. For any readers skeptical about Applied History as a public-policy venture, it is worth pausing to consider the opposite: if history had no utility or application, it would mean functioning like an amnesiac, repeating old mistakes, and rediscovering past successes. ${ }^{8}$

Black and dissident protest movements surged in the United States in the 1960s, amid police violence, white nationalism, and the war in Vietnam. They became part of America's Cold War. Recent scholarship has advanced our understanding about black and other protest movements in America, which were separate, but in the minds of embattled White House officials appeared connected. ${ }^{9}$ Even in recently published studies about them, however, one subject remains conspicuously missing: clandestine Soviet support. Such published works thus omit what the US intelligence community was trying to detect. ${ }^{10} \mathrm{~A}$ large body of research now exists about the FBI's surveillance of Civil Rights leaders, like Martin Luther King, and groups like the Black Panthers. ${ }^{11}$ Remarkably little, however, has been written about the cia's related

575-588; Marc Trachtenberg, The Craft of International History: A Guide to Method (Princeton: Princeton University Press, 2006).

Richard E. Neustadt and Ernest R. May, Thinking in Time: The Uses of History for Decision Makers (New York: Collier Macmillan, 1986).

8 Francis Gavin, "Thinking Historically: A Guide for Strategy and Statecraft," War on the Rocks, November 19, 2019, https://warontherocks.com/2019/11/thinking-historically-a-gui de-for-strategy-and-statecraft/.

9 Elizabeth Hinton, America on Fire: The Untold History of Police Violence and Black Rebellion Since the 196os (New York, NY: Liveright, 2021); Belew, Bring the War Home.

10 Otherwise excellent studies that do not mention the KG B include: Belew, Bring the War Home; Hinton, America on Fire; Peniel E. Joseph, Stokely: A Life (New York: Civitas Books, 2014); Peniel E. Joseph, The Sword and the Shield: The Revolutionary Lives of Malcolm X and Martin Luther King Jr. (New York: Basic Books, 2020).

11 Nelson Blackstock, Cointelpro: The FBI's Secret War on Political Freedom, 3rd edition (New York: Pathfinder, 1988); Ward Churchill and Jim Vander Wall, Agents of Repression:The FBI's Secret Wars Against the Black Panther Party and the American Indian Movement (Boston: South End Press, 1990); John Drabble, "From White Supremacy to White Power: The FBI, cointelpro-white hate, and the Nazification of the Ku Klux Klan in the 197os," American Studies 48, no. 3 (September 1, 2007): 49-74; Kristen Hoerl and Erin Ortiz, "Orga- 
spying program on the Left and Civil Rights movements. ${ }^{12}$ Even in 2020, half a century after the events described below, US records are being unsealed that cast new light about the conversations and decisions that led to the CIA spying on Americans. ${ }^{13}$

A wealth of declassified US intelligence records-thousands of pages of previously classified reports - together with US official inquiries, memoirs of American statesman and intelligence officers, as well as formerly classified Soviet intelligence material, are used here to offer a fresh interpretation about US spying on American race and dissident movements. Our discussion proceeds in three sections: first, it explores the influence of Soviet intelligence on American race and protest movements, second it assesses intelligence collection ("spying") by US agencies on those movements, and third it draws lessons from these historical chapters for American policymakers and society today. Old papers tell new stories about racial injustice in America and an executive branch sanctioning illegal spying on its citizens.

Over fifty years before the death of George Floyd, racial tensions boiled over in the summer of 1967 , leading to widespread protests. In four days of rioting in Detroit, 43 people were killed, and another 26 were killed in Newark. At the end of July, President Johnson appointed the National Commission on Civil Disorders, the Kerner Commission, to investigate and report on the origins of the riots. As Johnson later wrote in his memoirs, "until people realize that all the riots and demonstrations were not the product of conspiracy, there was little hope of persuading them to focus on fundamental causes-

nizational Secrecy and the FBI's Cointelpro-Black Nationalist Hate Groups Program, 1967-1971," Papers in Communication Studies 29, no. 4 (January 1, 2015): 59o-615; Joseph, Stokely; Joseph, The Sword and the Shield.

12 Notable exceptions include: Angus Mackenzie, Secrets: The CIA's War at Home (Berkeley: University of California Press, 1999); Frank J. Rafalko, MH/CHAOs: The CIA'S Campaign Against the Radical New Left and the Black Panthers (Annapolis: Naval Institute Press, 2011); other studies include: Theoharis, Spying on Americans; Mark Riebling, Wedge: The Secret War Between the FBI and CIA (New York: Knopf, 1994); Christopher Andrew, For the President's Eyes Only: Secret Intelligence and the American Presidency from Washington to Bush (New York: HarperCollins, 1995); John Prados, The Family Jewels: The cIA, Secrecy, and Presidential Power (Austin, TX: University of Texas Press, 2013); Douglas Brinkley and Luke Nichter, The Nixon Tapes: 1973 (New York: Houghton Mifflin Harcourt, 2015); Johnson, A Season of Inquiry.

13 John Prados and Luke Nichter, "Spying on Americans: Infamous 197os White House Plan for Protest Surveillance Released," NSA GWU, June 25, 2020, https://nsarchive.gwu.edu/ briefing-book/intelligence/202O-o6-25/spying-americans-new-release-infamous-huston -plan. 
on poverty, discrimination, inadequate schooling, substandard housing, slums and unemployment." ${ }^{14}$ In private, however, at the time Johnson believed that a large conspiracy lay behind the race riots, as well as the growing anti-war movement against the Vietnam War, both of which undermined his American Great Society. ${ }^{15}$ Despite no evidence of a conspiracy, Johnson looked to the US intelligence community to investigate. Given the supposed foreign direction of domestic dissident movements, America's foreign intelligence agency was the obvious clandestine agency to investigate. As Richard Helms, the Director of Central Intelligence (CIA Director) from 1966 to 1973, later recalled: "LBJ simply could not believe that American youth would on their own be moved to riot and protest against U.S. foreign policy."16 This was the origin of the CIA's controversial, and illegal, almost seven-year long intelligence collection program that involved domestic surveillance on dissident movements within US society. As Helms later recalled, nothing in his thirty-year intelligence career brought him more criticism than the CHAOS program after it was exposed in 1974. The unhappy codename, CHAOs, was chosen because it was the next on the CIA list, but when it was later disclosed, made the program seem all the more sinister. ${ }^{17}$

As US cities literally burned in the summer of 1967 , Johnson instructed Helms to obtain proof that the direction, and funding, of the anti-war movement and domestic political turmoil was coming from abroad. Helms told the president that such an investigation would inevitably risk the Agency violating its founding legislative charter, which limited its activities to operations abroad, and forbade anything resembling domestic police or security activities. Helms recalled that LBJ listened for fifteen seconds and then said: "I'm quite aware of that. What I want is for you to pursue this matter, and to do what is necessary to track down the foreign communists who are behind this intolerable interference in our domestic affairs."18 The next day, on Johnson's instructions, Helms created a highly secretive and compartmentalized Special Operations Group (SOG) within the CIA to carry out the president's instructions. According to the Agency's highly sensitive (and now declassified) seven-hundred-page in-house chronicle of its past abuses, known as its "Family Jewels" report, compiled in

\footnotetext{
14 Lyndon B. Johnson, The Vantage Point: Perspectives of the Presidency, 1963-1969 (New York: Holt, Rinehart and Winston, 1971), 173.

15 Andrew, For the President's Eyes Only, 336.

16 Richard Helms, A Look Over My Shoulder: A Life in the Central Intelligence Agency (New York: Random House, 2003), 279; see also William Colby and Peter Forbath, Honorable Men: My Life in the CIA (New York: Simon \& Schuster, 1978), 313-317.

17 Helms, A Look Over My Shoulder, 279, 179.

18 Helms, 280.
} 
1973, CHAOS was a "worldwide program for clandestine collection and pooled information on foreign efforts to support/ encourage/ exploit/ manipulate U.S. extremism."19

Helms, known to his detractors as "Eminence Grease" on account of his slicked hair, housed the Sog inside the department in the cIA dedicated to catching spies, its Counterintelligence Staff. It was led by James Angleton, a somber and conspiratorially minded professional spy hunter, who now occupies a hall of fame-infamy-in CIA history. He tore the Agency apart in the 1960s searching for Soviet moles, who he believed existed in its ranks, based on a series of devastating Soviet espionage penetrations in early Cold War British intelligence. Helms chose to place the new highly sensitive group in the CIA, the SOG, under Angleton not because foreign meddling in domestic race and protest movements was a counterintelligence matter-it was, strictly, counter subversion-but instead because the culture of secrecy in Angleton's Staff allowed it to be compartmentalized and closed off from other Agency operations. This was logical for an operation requiring secrecy, but in the case of the sog, compartmentalization provided a cover for illegal ciA activities. Angleton's Staff, which reported directly to Helms, effectively offered a useful closet in which to bury a skeleton. Helms later tried to distance Angleton from the sog: "Jim did not ask for this arrangement nor did I consult him before leaving this sensitive baby at his door." ${ }^{20}$ However, declassified records reveal Angleton's involvement from the outset. The sog's first recorded authorization of an investigation was a memorandum, in August 1967, titled "Overseas Coverages of Subversive Student and Related Matters" from the cia's Deputy Director of Operations ("Plans"), Thomas Karamessines, to Angleton himself. ${ }^{21}$

Johnson's objective with investigating foreign meddling in domestic political dissident movements was legitimate. Soviet intelligence used covert actions, "active measures", to support and aggravate race and other protest movements in America. According to the long-serving KGB officer stationed in the United States in the 196os and 7os, Oleg Kalugin, the KG B did all it could to fan flames of

19 Central Intelligence Agency Records Search Tool (hereafter "CIA CREST"), "Family Jewels" (April 13, 1973), 591. This SOG is not to be confused with a separate "soG", which stood for Studies and Observations Group, which conducted intelligence activities in places like Laos.

20 Helms, A Look Over My Shoulder, 28o.

21 US Senate Church Committee, Final Report of the Select Committee to Study Governmental Operations with Respect to Intelligence Activities, 94th Cong. 2d sess. (Washington, DC: Government Printing Office, 1976), Book III, 691; NSA GWU, "CIA Matters, Memorandum from James A. Wilderotter" (January 3, 1975), Е B B No. 222, https://nsarchive2.gwu.edu/NSAEBB/ NSAEBB222/family_jewels_wilderotter.pdf. 
racial protests in the United States. It forged documents purportedly from US white supremacists to disseminate in black communities, and even ordered the bombing of a predominantly black area in New York, Harlem, with the intention of blaming it on a militant Jewish group. As Kalugin later recalled, "Our active measures knew no bounds," adding "we went after everybody." According to Kalugin: "I knew our propaganda was exaggerating the extent of racism in America, yet I also saw firsthand the blatant discrimination against black people. Again, I had no qualms about stirring up as much trouble as possible for the U.S. government. It was all part of the job."22 However, contrary to what Johnson and his White House successor assumed, Soviet active measures only ever amplified existing grievances and injustices in US society, and never created them from afresh. Soviet intelligence never had the capability to orchestrate domestic protest movements in the US, as Johnson, and then Nixon, feared and assumed. The wounds that the KGB exploited in US society, like racial injustice in the anti-war movement, were American-made, not foreign.

While the underlying concern behind the CIA's sog was valid-foreign meddling in domestic American protests-its operations, on presidential authority, soon became dangerously broad: to examine all the evidence from all possible sources indicating any foreign support to domestic political dissidents. As such, the SOG, given the codename CHAOS in 1969, expanded into an illegal collection program on US persons exercising their constitutional rights for political association, freedom of speech, and protest. In the course of chAOs, the Agency compiled a computer index system with another sinister-sounding codename, "HYDRA", which contained 300,00o names and had files on 7,200 US citizens. ${ }^{23}$ According to the Rockefeller Commission, which investigated cHAOS after the investigative journalist, Seymour Hersh, exposed it in 1974, the sog prepared 3,500 memoranda for internal use, disseminated 3,00o memoranda to the FBI, and 37 memoranda to other senior US officials. A separate Senate investigation into CHAOS explained:

As the material flowed into CHAOs from stations, domestic CIA components, and the FBI, it was analyzed, indexed and filed. Every name of individuals and organizations was extracted and referenced in the cen-

Oleg Kalugin, Spymaster: My 32 Years in Intelligence and Espionage Against the West (London: Smith Gryphon, 1994), 55 .

23 CIA CREST, "MHCHAOS (OPS/ITG)" (n.d.), https://www.cia.gov/readingroom/docs/CIA -RDP77Moo144Rooo80oo70057-8.pdf.; also see Jens Wegener "Order and chaos: the CIA's HYDRA database and the dawn of the information age" Journal of Intelligence History 19.1 (2020) 77-91. 
tral CHAOs computer system known as "HYDRA" ... If a report on one individual referred to others, their names would be indexed also. Any information which was received about an individual for whom CHAOS maintained a file, went into this file. There was no winnowing of the material before its entry into the permanent record system of cHAOs. Once the material was indexed and filed, the HYDRA computer system permitted its prompt retrieval. By checking a name in HYDRA, one could find all the cables, memoranda or other documents referring to that individual, whether he was the subject of the material or merely mentioned in passing ... In many instances the computer would refer a searcher to the file of another person, or some other CHAOs holdings in which the subject individual was mentioned, but there was not enough material to open a file. Thus, there were an estimated 300,000 Americans indexed in HYDRA, but only an estimated 7,500 Americans for whom actual files were maintained. ${ }^{24}$

Helms was the perfect person to conceive and oversee cHAOS. He was a veteran intelligence operations officer, working in the CIA's predecessor (the oss) in the Second World War, and then working in the CIA's Directorate of Plansas its operations department was known at the time, ironically named given that it frequently failed to plan. The sog collected intelligence about foreign involvement in domestic US dissident groups through espionage (human intelligence, or "spies" in common vernacular). It recruited individuals without existing political dissident affiliations, who, after "reddening" or "sheep dipping" to learn theory and jargon of the anti-Vietnam war "New Left" while attending colleges in the US, were sent by the CIA to pursue graduate studies in Europe. If they could wriggle their way sufficiently into dissident movements there, Helms reasoned, they may be able to catch a glimpse of foreign sponsorship inside the US. This was how US citizens came onto the CIA's radar and entered its HYDRA database. Although this in itself was enough to raise legal issues for the Agency about collecting intelligence on US persons, the problem was it then shared that collected intelligence with the FBI, in violation of its founding 1947 legislation, which forbid its involvement in domestic security functions. As Helms later noted, the Agency should have destroyed intelligence files collected on American citizens, not passed them to the Bureau. ${ }^{25}$

24 Church Committee Report, Book III, 695.

25 Helms, A Look Over My Shoulder, 281. 
From the outset, the Agency worked closely with the FBI on CHAOs. As Helms recalled, computer terminals hummed away with information about it passing between Langley and the Bureau, where William "Bill" Sullivan, who ran the Bureau's Internal Security Division, was in charge. Sullivan's background exemplified differences between the FBI and CIA at the time. Sullivan came from a humble Irish American family in rural Massachusetts, where he worked his way through college, became a schoolteacher, joined the Internal Revenue Service, and then the wartime FBI. He rose up the Bureau's ranks to become one of the closest colleagues to the long-serving head-busting FBI Director, J. Edgar Hoover, until he fired Sullivan in October 1971. Sullivan's fall was caused, it seems, by a perennial type of palace intrigue - his ambitions to become leader. (In typical Hoover style, Sullivan came back to his office one day to find the locks changed and his name removed from the door). ${ }^{26}$ Sullivan's counterpart in the CIA for CHAOS operations was a wartime US intelligence (oss) veteran, Richard Ober. ${ }^{27}$

Inside the Bureau, CHAOs was subsumed into its long-standing Counterintelligence Program ("CoIntelpro"), established in 1956 to disrupt the activities of the US Communist Party (CPUSA), and expanded to include a number of other domestic subversive groups, like the Socialist Workers Party, ${ }^{28}$ white supremacist groups like the Ku Klux Klan, ${ }^{29}$ the New Left, and black extremist groups like the Black Panthers. The F B I called them collectively "Rabble Rousers." ${ }^{30}$ The US Attorney General, Ramsey Clark, an otherwise liberalminded man, instructed Hoover, to "use the maximum resources" to discover whether there was "scheme or conspiracy by any group" behind the riots afflicting the US in 1967. At Clark's request, the FBI launched a "ghetto informant program" that recruited 4,067 informants over the next two years to provide

26 William C. Sullivan, The Bureau: My Thirty Years in Hoover's FBI (New York: Norton, 1979), 238-249.

27 HIA Richard Ober Papers (n.d.), Richard Ober Papers, Box 1, Folder 2; Helms, A Look Over My Shoulder, 280.

28 FBI Vault COINTELPRO, "Documents on COINTELPRO" (n.d.), https://vault.fbi.gov/cointel -pro/socialist-workers-party; Helms, A Look Over My Shoulder, 280.

29 For the FBI investigations into the Klan's communist connections, see FBI Vault coINTELPRo, "Counterintelligence Program, Internal Security, Disruption of Hate Groups" (September 2, 1964), 4-8, https://vault.fbi.gov/cointel-pro/White\%2oHate\%2oGroups/ white-hate-groups-part-o1-of-14/view; FBI Vault CoInTE LPRo, "Memorandum to Mr. W.C. Sullivan from F.J. Baumgardner, Re. Communist Party, USA Counterintelligence Program Internal Security" (January 6, 1965), Vol. 1, 22-26, https://vault.fbi.gov/cointel-pro/White $\% 20 H a t e \% 20$ Groups/white-hate-groups-part-o1-of-14/view.

30 NSA GWU, "Rabble Rouser Index" (August 4, 1967), 3, https://nsarchive.gwu.edu/docu ments/spying-americans-new-release-infamous-huston-plan/19a.pdf. 
intelligence on the "racial situation" and "racial activities." ${ }^{31}$ Its investigations spread out across predominantly black areas of major US cities, with field officers surveilling, conducting "black bag jobs" (break-ins) into dissident groups, and disrupting their activities. The FBI's disruptive actions effectively became subversion themselves. They included harassing targets, arresting them on false pretenses, and mailing propaganda to local news outlets and parents of student activists to discredit them. ${ }^{32}$ They also involved recruiting informants on university campuses, opening mail, tapping telephones, and monitoring food stamp use.

The FBI had unique intelligence about Soviet involvement in domestic US protest movements from one of its longest running counterespionage investigations: operation "SOLO", which involved a high-ranking CPUSA member, Morris Childs. An early member of the CPUSA, during a trip to Moscow in 1930, Childs had been recruited to work as an informer for Soviet intelligence. ${ }^{33}$ Childs acted as courier and liaison between the CPUSA and the Soviet leadership, visiting Moscow usually at least once a year in the 196os and 1970s. ${ }^{34}$ Though suffering from bad health after a heart attack in $1949,{ }^{35}$ Childs literally hobbled along to play a valuable role for Soviet leaders, briefing them on American political affairs, and carrying funds to support the American communist movement from Moscow to America, often via Canada. As editor of the CPUSA's newspaper, the Daily Worker, Childs (given the codename "кнАв", "нUв", by Soviet intelligence) was treated like royalty by Soviet leaders in Moscow, as well as other communist world leaders like Mao Tse-Tung ${ }^{36}$ and Fidel Castro's confidants. ${ }^{37}$ On account of his service to the Soviet Union, Childs was later, in

31 Church Committee Report, Book II, 75.

32 FBi Vault cointe LPRo, "Black Extremists Part 1: Memorandum to SAC Boston from Director, FBI, Re. Nation of Islam” (February 27, 1968), 46, https:/vault.fbi.gov/cointel-pro/ cointel-pro-black-extremists/cointelpro-black-extremists-part-o1-of/view.

33 John Barron, Operation Solo: The FBI's Man in the Kremlin (Washington, DC: Regenery Publishing, 1996), 22-24.

34 FB I Vault SOLO, "Background Data Regarding Development of CG 5824-S as F B I Informant and His Subsequent Advancement to National Leadership Position in Communist Party, USA" (n.d.), Vol. 11, 51; For his first trip as an FBI agent see, FBI Vault solo, "Memorandum from A.H. Belmont to L.V. Boardman" (August 30, 1957), Vol. 1, 19; FBI Vault solO, "Memorandum from sAc Chicago to Director, FBI" (March 4, 1958), Vol. 1, 49.

35 FBI Vault Solo, "Memorandum from sAC Chicago to Director, FBI" (April 7, 1959), Vol. 11, $15^{2 .}$

36 FBI Vault solo, "Meeting with Mao Tse-Tung” (n.d.), Vol. 8, 121.

37 FBI Vault solo, "Preparations of a Message from the Communist Party (CP), USA to the CP of the Soviet Union to Be Delivered through the CP of Canada" (May 27, 1960), Vol. 20, 196 for his meeting with Anibal Escalante. 
1975, awarded the Order of the Red Banner by Leonid Brezhnev himself at a Moscow banquet. ${ }^{38}$

However, since 1952, Childs had in fact secretly been a double agent working for the FBI. Codenamed "CG-5824-5",39 he remained an FBI agent for a staggering twenty-seven years. Childs provided "simply incredible and amazing" information to US intelligence and the White House about Soviet intentions and capabilities. ${ }^{40} \mathrm{He}$ revealed that the CPUSA's leadership worked hand in glove with the Kremlin. Over the course of his FBI counter-espionage career, Childs received more than $\$ 28$ million in cash from KGB officers and couriers which he delivered to the CPUSA, which the FBI secretly monitored and traced. In some cases, the CPUSA's leaders used the Kremlin's subsidies as personal slush funds, using it for their own lifestyles and even paying for their children's education. Thanks to Childs, the Bureau knew more about the CPUSA's laundered cash than CPUSA members themselves. ${ }^{41}$

The FBI's 125 volumes of declassified files on so Lo reveal the extent to which Soviet leaders intended to support domestic US race protests. They show a steady stream of Moscow's interest in, and effort to promote, the "Negro issue" within the United States. ${ }^{42}$ In 1958, Morris Childs's brother, also working as an FBI agent ("NY 649-S") inside the CPUSA, reported a boast by the Party Secretary in charge of "Negro and Southern Affairs", James Jackson, that the "most secret and guarded" people were "guiding" the great Civil Rights leader, Martin Luther King Jr. The FBI noted that the Kremlin asked Morris Childs to obtain a copy of King's first book, Stride Towards Freedom, written with the help of the former member of the CPUSA underground, Stanley Levison, a New York lawyer

38 Christopher Andrew and Vasili Mitrokhin, The Sword and The Shield:The Mitrokhin Archive and The Secret History of The KG B (New York: Basic Books, 1999), 290.

39 It appears that "CG" stands for Chicago, where Morris Childs lived, and thus the FBI field office that handled him.

40 FBI Vault SOLO, "Letter from J. Edgar Hoover to Richard Nixon, Vice President" (July 25, 1958), Vol. 1, 157-160; "Memorandum from Roach to A.H. Belmont” (August 2, 1958), Vol. 2, 41; "Memorandum from SAC New York to Director, F B I" (July 22, 1958), Vol. 2, 42-66; "Memorandum from R.O. L' Allier to Belmont" (January 13, 1961), Vol. 27, 47. FBI Vault SOLO, "Memorandum from F.J. Baumgardner to A.H. Belmont" (August 25, 1959), Vol. 13, 49-50; "Memorandum from SAC New York to Director, FBI" (January 25, 1966), Vol. 99, 38-42; "Memorandum from SAC New York to Director, FBI" (September 5, 1967), Vol. 116, 240-243.

See FBi Vault solo, "Memorandum from sAC Chicago to Director, FBI" (August 29, 1958), Vol. 6, 15; "Discussion between James Jackson and Nikolai Mostovets Re. 'Material Aid' for the Communist Party, USA" (August 18, 1959), Vol. 11, 181; "Information Concerning Material on the Negro Question in the U.S. Which Was Left with John Bittman by James Jackson" (August 12, 1960), Vol. 11, 209. 
and entrepreneur. This evidence, meagre thought it was, about the CPUSA's clandestine connection with King was electrifying for Hoover. soLo's intelligence helped to convince him that Moscow was behind race protests in the United States. In fact, by arriving at this conclusion, Hoover failed to differentiate Soviet intentions from capabilities. While the Kremlin indeed intended to assist dissident movements in America, through the CPUSA, it did not have the capability to create a conspiracy. Soviet intelligence archives now reveal that the KG B never considered black US activist groups, like the Black Panthers, as sufficiently orthodox to Soviet ideological worldview. The same was the case with student protesters in America, who the KG B considered unwieldy. ${ }^{43}$ It does not appear the FBI discovered this crucial information.

It is impossible to quantify the impact of Hoover's personal racism and bigotry (his known dislike of "Blacks and Jews") on the Bureau's misguided view that domestic racial justice movements in US society were orchestrated from outside-and thus valid targets for investigation and harassment. ${ }^{44}$ Hoover grew up in Washington, DC, which was a largely segregated city, but his racism was part of much larger problems of race within US society. In 1968, George Wallace, governor of Alabama, ran as a third-party candidate in the presidential election on an expressly segregationist platform. He carried five states in the Deep South, with his segregationist platform attracting millions of alienated white voters.

Hoover's FBI kept Martin Luther King under close surveillance, as it did the National Association for the Advancement of Colored People (NAACP) on account of its apparent association with the CPUSA. The US attorney general, Robert F. Kennedy, brother to President John F. Kennedy, had originally ordered the bugging ("technical surveillance") of King's hotel rooms in 1963 on account of the general "communist influence in the racial situation", and his influence under the CPUSA's secret member, Levison, in particular. ${ }^{45}$ Hoover was insistent that King was under communist influence, and obsessed that he was a "tomcat" with deviant sexual urges. In a public press conference in 1964, Hoover had labelled King "the most notorious liar in the country." When the Bureau's bugs in King's hotel bedrooms revealed his adulterous affairs, Hoover found

\footnotetext{
43 Andrew and Mitrokhin, The Sword and The Shield, 309.

44 FBi Vault Cointelpro, "Memorandum from SAC Philadelphia to Director, FBi Re. Counterintelligence Programs Black Nationalist-Hate Groups" (August 30, 1967), Vol. 1, 6-9 describes FBI harassment ("Disruption") of "an extremist Negro" group in Philadelphia, RAM.

45 Athan G. Theoharis, ed., From the Secret Files ofJ. Edgar Hoover (Chicago: Ivan R. Dee, 1991), 94-97.
} 
them so entertaining that he reportedly played some of the recordings to his confidants. Thereafter, the F BI Director carried out a personal vendetta against King and other leaders of the civil rights movement. ${ }^{46}$ Hoover harassed and discredited him, authorizing his deputy, Sullivan, to send a tape recording of one of his affairs to his wife, the Civil Rights leader Coretta Scott King.

Contrary to what Hoover believed, Soviet intelligence never considered King an asset for the Soviet cause while he was alive. His leadership of the Civil Rights movement was based not on a rejection of US society, as Soviet leaders and their spy chiefs hoped, but rather a desire for African Americans to be given equal share of the American dream. The KG B disapproved of the Black Panthers, whom the Civil Rights activist, Stokely Carmichael, joined in 1968. Despite its surveillance on Carmichael, it again does not appear the FBI ever discovered the KGB's distrust of him. Matters changed for the KG в after King's assassination in April 1968, which led to 125 race riots in American cities. His memory thereafter became a persistent target for Soviet active measures to discredit the US government and divide its society. With bitter irony, King was thus a target for both FBI and Soviet KG B active measures.

On November 15, 1967, Helms personally delivered to Johnson the results of the CIA's study on the "International Connections of the U.S. Peace Movement." 47 It concluded there was little evidence of foreign involvement, and no evidence of any significant foreign financial support, of peace protest activities within the United States. The report was a disappointment to Johnson. However, far from accepting its conclusion, Johnson instructed the Agency to intensify its search for foreign influence, convinced that the conspiracy remained alive and hidden. Five days after delivering his dissatisfying report to the White House, Helms instigated a new CIA study, at Johnson's request, focusing on antiwar demonstrations in the US and abroad. After King's assassination in April in 1968, and Robert Kennedy's fatal shooting two months later, in August that year CIA station chiefs abroad were informed that CHAOs was a "high-priority program" and instructed its foreign liaison officers to investigate foreign contacts with what was described as "the radical left" amounting to a vast, violent, anti-government conspiracy: "radical students, antiwar activists, draft resisters and deserters, black nationalists, anarchists, and assorted new leftists." 48

\footnotetext{
46 Church Committee Report, Book III, 79-184; Andrew, For the President's Eyes Only, 364.

47 Rockefeller Commission Report, Report to the President by the Commission on cIA Activities within the United States, 1975, 133, https://www.fordlibrarymuseum.gov/library/document/ ooo5/1561496.pdf.

48 Church Committee Report, Book III, 694.
} 
Championing his election platform of "law and order", the new US president, Nixon, viewed violent domestic protest movements in US society like his predecessor, and likewise used the US intelligence community to provide evidence that supported his preconceived conclusions. In January 1969, after taking office and seeing television reports of student demonstrations from Paris to Tokyo, Nixon instructed: "I want to have a CIA analysis in-depth of communist factors in youth disturbance."49 As a former member of the US House Un-American Activities Committee during his Congressional tenure in the early Cold War, Nixon needed little persuading about the existence of a worldwide conspiracy organized by the Kremlin. Like Johnson, he was convinced that "communist factors" were guiding such demonstrations, and was skeptical, and dismissive, of intelligence that reached different conclusions. Faced with a president incredulous about views to the contrary, the only way that the CIA could convince Nixon that domestic dissent was not part of an international communist conspiracy was by continuing and expanding the scope of CHAOs. "Only by being able to demonstrate that it investigated all antiwar persons and all contacts between them and any foreign person could cIA 'prove the negative' that none were under foreign domination," a subsequent investigation stated. ${ }^{50}$ Thus, the CIA's CHAOs program turned into an enormous effort to prove a negative for a disbelieving president and his advisers. On February 18, Helms wrote to Nixon's National Security Adviser (and later Secretary of State), Henry Kissinger, with his report about foreign involvement in domestic protest movements, "Restless Youth":

Herewith is a survey of student dissidence worldwide as requested by the president. In an effort to round out our discussion of the subject, we have included a section on American students. This is an area not within the charter of this Agency, so I need not emphasize how extremely sensitive this makes the paper. Should anyone learn of the existence, it would prove most embarrassing for all concerned. ${ }^{51}$

The CIA's study concluded that the motivations underlying student radicalism came from social and political alienation at home, not the work of foreign

49 Andrew, For the President's Eyes Only, 354.

50 Church Committee Report, Book II, 101-102.

51 CIA CREST, "Student Unrest-Memorandum for Henry A. Kissinger from Richard Helms" (n.d.), 7, https://www.cia.gov/library/readingroom/docs/LOC-HAK-1-2-21-4.pdf; Church Committee Report, Book III, 696; cia CREst, "The cia Document 'Restless Youth' ..." (June 10, 1975), https://www.cia.gov/library/readingroom/docs/LOC-HAK-424-4-10-5.pdf. 
conspiracy. Kissinger disputed its findings, and Nixon was predictably dissatisfied. ${ }^{52}$ It did not occur to either the president or his national security adviser that it was not CIA intelligence collection, but instead their preconceived ideas, like Johnson's previously, which were in error. The Agency's failure to discover a communist conspiracy behind campus revolts reinforced Nixon's conviction that it was run by "Ivy League liberals" - terms of disdain in Nixon's vocabulary. Nixon had a longstanding distrust of US intelligence, particularly the CIA. During his failed 1960 presidential bid, he was convinced that the CIA leaked intelligence supporting Kennedy's public campaign claims about the existence of a US-Soviet "missile gap." ${ }^{33}$ As the sitting vice president, Nixon knew from US intelligence reports - based on U-2 imagery analysis - that the missile gap was in fact non-existent. In his 1962 memoir, Six Crises, Nixon revealed that if he had become president, he would have created a new organization outside the CIA for covert actions - a threat that cut to the heart of the Agency's work. ${ }^{54}$ Nixon was convinced that the cIA was staffed with "eastern elitists" and Kennedy men. This included men like the CIA officer on the cHAOs Program, Richard Ober, a third-generation Harvard graduate, prize oarsman, and part of the cosmopolitan "Georgetown cocktail set" that Nixon detested for being "soft". Nixon thus increasingly relied on Kissinger to provide him with his own summary of intelligence, acting as the president's chief intelligence officer, rather than using the Agency's briefers and its flagship President's Daily Brief (РDв). ${ }^{55}$ During the transition from Johnson to Nixon, stacks of envelopes containing PDB s piled up, unread, in Nixon's office. ${ }^{56}$ When the Agency later, in 1970, failed to provide Nixon with forewarning about the overthrow of Cambodia's president, he demanded: "What the hell do those clowns do out there in Langley?" (In fact, the CIA had hitherto been prevented from opening a station in Phnom Penh). ${ }^{57}$ As a highly intelligent and skillful lawyer, who was able to cross examine and humiliate his intelligence briefers, Nixon had worse relations with the

$5^{2}$ CiA crest, "Summary of cia Survey, 'Restless Youth'-Memorandum for the President from Henry A. Kissinger" (n.d.), 1-6, https://www.cia.gov/library/readingroom/docs/LOC -HAK-1-2-21-4.pdf; Andrew, For the President's Eyes Only, 355.

53 Andrew, For the President's Eyes Only, 350-351.

54 Richard M. Nixon, Six Crises (New York: Doubleday, 1962).

55 See Richard M. Nixon Presidential Library, "Memo for Dr. Kissinger 'Evening Notes'” (January 28, 1971), NSC Files Subject Files "HAK Evening Notes" Box 342.

56 William Burr, "Did Nixon Even Read the cia's Daily Briefs?," NSA GWU (blog), September 26, 2016, https://nsarchive.gwu.edu/briefing-book/intelligence/2016-o9-14/did-nixon -even-read-cias-daily-briefs.

Andrew, For the President's Eyes Only, 365. 
intelligence community than any other US president in history—until Trump half a century later.

In June 1969, the cIA provided Nixon and Kissinger with another report, "Foreign Communist Support to Revolutionary Protest Movements in the United States", which came to similar conclusions as its previous analysis, "Restless Youth": it stated that while communist regimes encouraged American protest movements through propaganda and exploitation of international conferences, there was little evidence of their funding and training of those movements, and no evidence of communist direction or control..$^{58}$ As Nixon's counsel for domestic affairs, John Ehrlichman, later a key figure in the June 1972 Watergate break-in and ensuing scandal, told the President, "the intelligence community conclusion is that our government does not have specific information or 'ironclad proof' that red China or Cuba is funding campus disorders." 59

Nixon, however, instructed the Agency to "keep after this." He ordered that a young former army intelligence officer and thirty-year-old White House lawyer, Tom Charles Huston, then working on special projects in the White House, "or someone of his toughness and brains," should be given the job of developing "hard evidence on this." The implication was that the Agency's lack of toughness and brains had prevented it from unearthing evidence that the president believed was there. "There was nothing we could do to convince him", Helms later recalled. In the summer of 1969, Helms personally geared up the Agency's efforts to "monitor those international activities of radicalism black militants which may adversely affect the national security."60 The main result of the invigorated CHAOS operation, under pressure from Nixon's White House, was to collect huge amounts of useless intelligence, all of which had to be analyzed in vain attempt to persuade a disbelieving president that it did not contain evidence of a vast international conspiracy. In September, Helms complained that the "backlog of undigested raw information" had become "a formidable obstacle." ${ }^{61}$

Nixon's belief in foreign involvement in domestic dissident movements reached a new level during violence waged by the Black Panthers, Weathermen, and other quasi-revolutionary movements in the summer of 1969. During the academic year 1969 to 1970 , there were 174 campus bombings and bombing attempts in the United States. Tragedy struck at Kent State University in Ohio where, in May 1970, National Guardsmen shot and killed four student

\footnotetext{
$58 \quad$ Rockefeller Commission Report, 135.

59 Andrew, For the President's Eyes Only, 365-367.

60 Andrew, 355 .

61 Rockefeller Commission Report, 142.
} 
demonstrators. That same month, close to 100,000 demonstrators began converging on the White House for mass demonstrations. Nixon and Kissinger retreated into a siege mentality. For Kissinger it seemed that "the very fabric of government was falling apart. The executive branch was shellshocked."62 The following year, the cia provided Nixon and Kissinger with another report, "Definition of Existing Internal Security Threat-Foreign", which again concluded there was no evidence, based on its available information and sources, that foreign governments like the Soviet Union, and their intelligence services, were controlling domestic dissidents' movements or capable of doing so. ${ }^{63}$

Despite CIA assessments to the contrary, Nixon continued to believe in the existence of a communist conspiracy orchestrating domestic dissent. "President Nixon was insatiable in his desire for intelligence," said Deke DeLoach, FBI Deputy Associate Director: "He would constantly ask the F BI for more and more intelligence to prove that the riots in our country were being caused by insurgent groups in foreign countries. And they weren't." The architect of coINTELPRO, Sullivan, pressured his Bureau underlings. He "gave us hell because we couldn't prove that the Soviets were behind radical and student unrest", according to a young FBI agent at the time; "We knew they were not. Nothing would have scared the Soviets more than these students." ${ }^{64}$

Hoover's always strained relations with the rest of the US intelligence community reached a new low in the spring of 1970, just as the domestic anti-war movement was reviving. The CIA refused to supply him with the name of an FBI agent who had assisted the Agency without first seeking Hoover's permission. ${ }^{65}$ As a result, Hoover dramatically cut off liaison with the rest of the US intelligence community. To make his point even more forcefully, Hoover decided to discontinue the illegal methods of investigation that he had employed for previous presidents, including mail openings and black bag jobs against American citizens, both of which Nixon regarded as essential tools in uncovering the secret communist conspiracy. Against Nixon's wishes, Hoover also began limiting the recruitment of campus informants to men over the age of twenty-one. As Hoover said:

For years and years and years I have approved opening mail and other similar operations, but no. It is becoming more and more dangerous and we are apt to get caught. I am not opposed to doing this, I'm not opposed to

\footnotetext{
62 Andrew, For the President's Eyes Only, 365.

63 Church Committee Report, Book III, 700.

64 Tim Weiner, Enemies: A History of the FBI (New York: Random House, 2013), 289.

65 Riebling, Wedge, 253.
} 
continuing the burglaries and the opening of mail and other similar activities, providing somebody higher up than myself approves of it ... [If] the Attorney General or some high-ranking person in the White House [does so] - then I will carry out the decision. But I'm not going to accept responsibility myself anymore, even though I've done it for many years. ${ }^{66}$

In June 1970, all of Nixon's frustrations with the intelligence community erupted at a meeting in the Oval Office. According to General Donald Bennett of the Pentagon's Defense Intelligence Agency, "the president chewed our butts." ${ }^{67}$ Nixon instructed his intelligence chiefs to establish an inter-agency committee on intelligence, under Hoover's chairmanship, to "recommend the steps which would strengthen the capabilities of the government to collect intelligence on radicals." This was the origins of the forty-three-page so-called "Huston plan", which, declassified records now confirm, proved to be a bridge too far even for Nixon. ${ }^{68}$ The plan was put together by the White House lawyer, Huston. Hoover inevitably dismissed Huston as a "hippie intellectual", while Nixon fondly called him an arrogant son of a bitch. On Nixon's instructions, the interagency committee laid out "the pros and cons of various collection methods" in an options paper. The committee reported their findings to the president at the end of June 1970. In his memoirs, Nixon described the report in a lawyerly way, distinguishing between radical domestic groups and "Communist infiltrators", and noting that it "differentiated radical terrorist groups from those that merely indulged in incendiary rhetoric." 69

Nixon's recollections about the Huston Plan targeting "militant new Left Groups" and "Black extremist" groups are confirmed by now unsealed records. ${ }^{70}$ Huston tried to secure Nixon's approval for the "strongest options" in the report to remove "current restrictions" on domestic spying, but at least two of those methods were illegal. Huston advised the president, "Covert [mail] coverage is illegal, and there are serious risks involved. However, the advantages to be derived from its use outweigh the risks." Huston similarly viewed "surreptitious entry" as a technique that was "clearly illegal, ... highly risky, ... and could

66 Church Committee Report, Book III, 942.

67 Andrew, For the President's Eyes Only, 366.

68 Prados and Nichter, "Spying on Americans."

69 Richard M. Nixon, RN: The Memoirs of Richard Nixon (New York: Grosset \& Dunlap, 1978), 473 .

70 NSA GWU, "Special Report, Interagency Committee on Intelligence (Ad Hoc) 'Huston Plan'-Report for the President” (June 25, 1970), https://nsarchive.gwu.edu/documents/ spying-americans-new-release-infamous-huston-plan/o1a.pdf; Brinkley and Nichter, The Nixon Tapes: 1973, 684-699. 
result in great embarrassment if exposed." Still, he concluded that "it is also the most fruitful tool and can produce the type of intelligence which cannot be obtained in any other fashion." ${ }^{71}$

Nixon approved the Huston plan on July 14, 1970. In his memoirs, he does not mention its illegality, simply stating that he felt it "necessary and justified by the violence we face ... The express domestic targets - the Black Panthers and the Weatherman - had announced their intentions to kidnap and assassinate and were already building up an arsenal of weapons to carry out their threat." However, Nixon refused to sign the plan himself, and instead left it to Huston to inform Hoover about his approval. Hoover was outraged because he had requested specific instructions from the president to "lift the various investigative restraints" - to conduct otherwise illegal spying. In an extraordinary about-face, on July 28 , 1970, Nixon withdrew his approval of the Huston plan. His explanation for doing so in his memoirs was staggering, and a revealing insight into the intersection between US intelligence and the US presidency. Nixon effectively declared himself powerless over his FBI Director:

I knew that if Hoover had decided not to cooperate, it would matter little what I decided or approved. Even if I issued a direct order to him, while he would undoubtedly carry it out, he would see to it that I cause to reverse myself. There was even the possibility that he would resign in protest. ${ }^{72}$

It seems the real reason why Nixon refused to proceed with the Huston plan was that he was unwilling to take responsibility for it himself, preferring instead for his intelligence chiefs to do so. His failure to implement the Huston plan contributed to Nixon's decision, in 1971, to establish a secret group in the White House, "the plumbers", who would deploy some of the techniques previously resisted by Hoover to investigate leaks of classified information. Thus began Nixon's walk down the primrose path from the Oval Office to Watergate. ${ }^{73}$

The CIA's CHAOs program was exposed, in all but name, by the investigative journalist, Seymour Hersh, in December 1974. ${ }^{74}$ His reporting precipitated three US government investigations into it and other US intelligence abuses issues, the Rockefeller Commission, established by presidential executive order

\footnotetext{
71 Church Committee Report, Book IV, 278.

72 Nixon, RN: The Memoirs of Richard Nixon, 474-475.

73 Andrew, For the President's Eyes Only, 361, 369-37o.

74 "Huge c.I.A. Operation Reported in U.S. Against Antiwar Forces, Other Dissidents in Nixon Years," The New York Times, December 22, 1974, https://www.nytimes.com/1974/12/ 22/archives/huge-cia-operation-reported-in-u-s-against-antiwar-forces-other.html.
} 
under the chairmanship of the vice president, Nelson Rockefeller, whose members included the future US president, Ronald Reagan. ${ }^{75}$ The US Senate established a Select Committee to Study Governmental Operations with respect to Intelligence Activities, with Senator Frank Church as chairman (the "Church Committee"). ${ }^{76}$ The House of Representatives established its own Select Committee on Intelligence, chaired by Lucian Nedzi, and then Otis Pike (the "Pike Committee"). ${ }^{77}$ Together, their exposures turned 1975 into the "year of intelligence." Church, in particular, reveled in sensational stories of CIA abuses that his Senate committee uncovered. When it began public hearings, in September 1975, Church and committee members posed for the cameras, holding a CIA silent electric powered gun designed to fire lethal poison darts-absurdly designated, in official Agency jargon, a "Nondiscernible Microbionoculator". In a phrase that instantly created headlines, Church claimed in July that the CIA may have been "acting like a rogue elephant on the rampage."78 The phrase was both misleading and damaging to US national security. Soviet intelligence seized on it for its propaganda and disinformation campaigns to discredit US government and its intelligence community. ${ }^{79}$

Church was driven by his own political aspirations to establish himselfunsuccessfully, as it transpired-as a leading contender for the Democratic nomination in the next presidential election. His political ambition for the White House could not, therefore, involve tarnishing the reputations of previous Democratic presidents, who had authorized domestic break-ins, wiretaps, and surveillance of American race and other dissident protest groups. For Church, the CIA thus became a politically convenient scapegoat. In private, however, he was more nuanced about the source of Agency abuses: "the CIA operated as an arm of the presidency. This led presidents to conclude that they were 'super godfathers' with enforcers. It made them feel above the law and unaccountable." ${ }^{80}$ The Rockefeller Commission came to similar conclusions: "The presidential demands upon the CIA appear to have caused the Agency to forgo, to some extent, the caution with which it might otherwise

\footnotetext{
75 HIA Richard Ober Papers (n.d.), Ober Papers, Box 5, Folder 4.

76 HIA Richard Ober Papers (n.d.), Ober Papers, Boxes 7-9.

77 John Prados and Arturo Jimenez-Bacardi, "The White House, the cia and the Pike Committee, 1975," NSA GWU, June 14, 2017, https://nsarchive.gwu.edu/briefing-book/intelligen ce/2017-06-o2/white-house-cia-pike-committee-1975.

78 John M. Crewdson, "Church Doubts Plot Links to Presidents," The New York Times, July 19, 1975, https://www.nytimes.com/1975/o7/19/archives/church-doubts-plot-links-to-preside nts-church-doubtful-on-links-to.html.

79 Andrew and Mitrokhin, The Sword and The Shield, 230.

8o Andrew, For the President's Eyes Only, 421.
} 
have approached the subject." ${ }^{81}$ Helms agreed with that conclusion, but, as he later stated, a more accurate and blunt way of stating the same thing was that, without the president's insistence, the CIA would never have investigated or reported on anything touching on domestic political violence. ${ }^{82}$ When it came to foreign and domestic US covert actions, the real rogue elephant was not the CIA, as Church suggested, but in fact those sitting behind the Oval Office's Resolute Desk.

As Nixon's successor, Gerald Ford, bluntly told editors of the New York Times in January 1975 after the Church Committee was established, it would be against the national interest to release intelligence records because they would "blacken the reputation of every President since Truman." When the editors immediately asked, "Like what?", the president replied, "Like assassinations," hastily then adding, "That's off the record." 83 The nature of US intelligence leaks in Washington guaranteed that it did not remain off the record for long.

The application of history has limitations: the past never repeats itself. No two situations are identical. That said, the history of political protest movements and riots in America in the late 196os and early 1970s provides warnings about the dangers of a conspiratorially minded president, who uses his intelligence community to perform otherwise illegal spying. In his memoirs, Nixon gave an unapologetic defense of the "justified and responsible" proposals put to him in the Huston plan in the face of domestic terrorism and violence:

It is clear that when a nation confronts a dire situation someone is going to act. People will not stand by and let criminals destroy life and property. If the president does not decide how to meet the emergency, someone at a lower level will. I would rather it be the president exercising his judgment than an FBI agent in the field. ${ }^{84}$

Nixon's words rhyme - to use Mark Twain's reputed phrase about historywith the widespread protests that have erupted in America in 2020 for racial equality. President Trump described himself as a "law and order" president much like Nixon did in the 1968 election year. Like Johnson and Nixon, Trump was - and apparently still is - convinced that political protests, and violent riots, in America were the work of a hidden conspiracy, ANTIFA, and "profes-

\footnotetext{
$81 \quad$ Rockefeller Commission Report, 131.

82 Helms, A Look Over My Shoulder, 282.

83 Andrew, For the President's Eyes Only, 405.

84 Nixon, RN: The Memoirs of Richard Nixon, 475.
} 
sional anarchists", rather than stemming from underlying political, economic, and social inequalities. Parallels between Trump and Nixon stretch even further, from their disastrous relations with the US intelligence community, to being subjects of impeachment proceedings by the House of Representatives, and their predisposition to conspiracy theories. However, it would be misleading to draw too many parallels between them. The context in which the US intelligence community operates today is fundamentally different from when the CIA ran CHAOS. Revelations of US intelligence abuses in 1975, the "year of intelligence", led to wholesale legal reforms restricting the ability of US agencies to collect intelligence on US persons, which still exist today.

While today's legal and operational context for collecting intelligence differs from the past, the principle of spying on Americans to find a hidden conspiracy behind protest movements remains alive-and just as alarming from a civil liberties perspective. Helms described the dilemma that he, as CIA head (DCI), was put in by Johnson and Nixon with CHAOs: what should happen, "come crunch time", when a "president orders his DCI to step out of bounds?" he asked. Faced with that situation today, a contemporary US intelligence agency, manned by an industry of lawyers, would first and foremost seek legal indemnity from the president for itself and its officers performing otherwise illegal acts. There is thus a good reason why US covert action is called "executive action" - its legal authority is derived from the president. However, apart from a legal defense to performing otherwise illegal spying, the dilemma outlined by Helms still reaches to the heart of the nexus between US intelligence and the presidency today:

If, after reminding the President of the Agency's charter restrictions and suggesting any appropriate alternatives, the President remains insistent, what is the DCI to do? He is neither a policymaker nor a judicial officer. Has he the authority to refuse to accept a questionable order on a foreign policy question of obvious national importance? If the President's directive cannot be deflected, the DCI's responses range from acceptance to outright refusal and presumably resignation. ${ }^{85}$

The hangman's choice for the head of US intelligence described by Helms still exists. One way to prevent US intelligence abuses, like spying on legitimate domestic protest movements, is for a robust internal whistleblowing procedure to operate within the US intelligence community and its Congressional

85 Helms, A Look Over My Shoulder, 282. 
oversight bodies. That did not exist at the time of CHOAS. If it had, it seems reasonable to assume that those in the FBI, CIA, and Executive Branch, who discovered the Program's existence, and were alarmed about it, may have used such a procedure to raise alarm about CHAOS.

Today the US federal government has whistleblowing procedures, but they are imperfect. The Trump administration strained them to breaking point. ${ }^{86} \mathrm{In}$ the face of an iconoclastic and vendetta-driven chief executive, whistleblowing may not seem a viable option. But it is precisely at these extreme moments, when the US constitution and legal norms are attacked, that it becomes most important for a robust whistleblowing procedure to operate. It would therefore be advisable for the US government to instigate policies to safeguard the effective functioning of whistleblowers in the most extreme moments of executive action. In light of Trump-like Nixon, a striking example of executive branch overreach - the US government would be well advised to adopt reforms like: passing legislation expressly preventing whistleblowers from being punished by retaliatory investigations, confirming their confidentiality, a breach of which itself would constitute grounds for a legal action by a whistleblower, and granting them right to a jury trial if a whistleblowing complaint body fails to deliver a judgement in requisite time. ${ }^{87}$

Another available mechanism to prevent illegal spying on Americans is political oversight. US intelligence agencies now operate under Congressional oversight in ways lacking at the time of CHAOs. Unfortunately, however, as scholars like Amy Zegart have demonstrated, Congressional oversight of US intelligence is declining in effectiveness. ${ }^{88}$ The way to increase its effectiveness may lie in creating new formal oversight architecture. But in the time-honored tradition, creating a new layer of bureaucracy is not necessarily advisable. Instead, an innovative approach would be for the US government to concentrate on advancing informal oversight. Here universities and schools of public policy have important roles to play: they can offer courses, and executive education programs, to teach best practices about Congressional oversight of US intelligence. An effective way of doing so is Applied History: case studies of past successes and failures. Awareness about what has worked in the past, and not, is a valuable starting point for those in, or about to join, public

86 Kaeten Mistry and Hannah Gruman Whistleblowing Nation. The History of National Security Disclosures and the Cult of Secrecy (Columbia University Press 2020)

87 "Maloney Leads Bipartisan Group of Members in Introducing Whistleblower Protection Improvement Act," House Committee on Oversight and Reform, May 4, 2021.

88 For example, Amy B. Zegart, "The Domestic Politics of Irrational Intelligence Oversight," Political Science Quarterly 126, no. 1 (2011): 1-25. 
service with responsibility for overseeing America's eighteen different intelligence agencies.

Given today's interconnected digital world, with the proliferation of private sector intelligence collection platforms, there should be no illusions about challenges facing effective oversight compared even to the recent past. There is evidence that police forces in the United States have intruded from their traditional jurisdiction, law enforcement, to perform intelligence-gathering functions. Thanks to new collection capabilities, they have unprecedented opportunities to spy on Americans. ${ }^{89}$ The legal and oversight framework for them doing so is opaque..$^{90}$ To make matters worse, in the highly polarized social context of intelligence in the United States in the third decade of the twenty-first century, even the procedure of oversight itself has become politicized. The perennial issue for US intelligence, to which its history has no easy answers, remains: when whistleblowing and oversight are ineffective, who watches the watchers?

\section{Acknowledgments}

I would like to thank colleagues at the Intelligence Project and Applied History Project at Harvard's Kennedy School of Government (HKS). In particular, my thanks go to Sean Power, Poornima Rajeshwar and Diane Lang, Research Assistant and Summer Interns at the HKs Intelligence Project respectively, for their help with this article. Any mistakes in it are entirely mine, not theirs.

89 Kashmir Hill, "The Secretive Company That Might End Privacy as We Know It," The New York Times, January 18, 2020, https://www.nytimes.com/2020/o1/18/technology/clearview -privacy-facial-recognition.html; Shoshana Zuboff, The Age of Surveillance Capitalism: The Fight for a Human Future at the New Frontier of Power (New York: PublicAffairs, 2019).

$90 \quad$ Rebecca Heilweil, "Why We Don't Know as Much as We Should about Police Surveillance Technology," Vox, February 5, 2020. Unattributable author interview with senior FBI agent responsible for liaison with a major police force intelligence unit (April 12, 2019, May 5, 2019). 